\title{
A TEN YEAR PREVALENCE STUDY OF MAREK'S DISEASE AND AVIAN LEUKOSES AT IBADAN, NIGERIA
}

\author{
O. O. FATUNMBI, D. F. ADENE \\ Department of Veterinary Medicine, University of Ibadan, Ibadan, Nigeria
}

Received August 8, 1984

\begin{abstract}
Fatu nmbi O. O., D. F. Adene: A Ten year Prevalence Study of Marek's Disease and Avian Leukoses at Ibadan, Nigeria. Acta Vet. Brno, 55, 1986: 49-53.

Diagnostic studies were undertaken on the prevalence of Marek's disease (MD) and Avian Leukoses (AL) between 1975 and 1984. Over the period, 22 cases of outbreaks of MD and 19 cases of outbreaks of AL were recorded. During this period, there were two noticeable peak incidence for MD in 1977 and 1983/84 while for AL there were three peaks in 1977, 1979 and 1983. It was observed that the lag period, from 1977 to 1983 , when MD incidence remained low reflected the effect of the widespread application of MD vaccines in the advanced poultry producing countries which supplied the bulk of the Nigerian poultry. The importance of diagnostic surveillance of MD is discussed.
\end{abstract}

Survey, diagnosis, local vaccination programmes.

Marek's disease (MD), a lymphoproliferative neoplasm of domestic fowl caused by a herpes virus, was a major disease problem and source of great economic losses in poultry until the early 1970's. The discovery of the turkey herpesvirus lyophilised vaccine for MD in 1970, was followed with progress in the control of the disease (Okazaki et al. 1970; Purch a se and Schultz 1978).

Although routine MD vaccination has to-day not been adopted in Nigeria, the poultry industry appeared to have benefitted from the spill-over effects of the vaccination standard and practices in the poultry exporting countries. For this reason and because of the pathological relationship between MD and Avian Leucoses (AL) which is another economically important neoplasm of poultry, a diagnostic surveillance for both diseases has been maintained in our Poultry Disease Unit (PDU) at the University of Ibadan. This paper describes the studies on MD and AL from 1975 up to date, and discusses the trend in the incidence as well as the possible implications of these observations on the epizootiology of MD.

\section{Materials and Methods}

Clinico-pathological studies: Carcasses submitted to our Poultry Disease Unit (PDU) originated mainly from Oyo State and occasionally from five neighbouring States namely Lagos, Ogun, Ondo, Kwara and Bendel. Each carcass was rountinely subjected to post mortem examination, paying attention to age of flock, changes in size, colour and the transectional appearances that might be suggestive of neoplastic growth in the major organs such as the liver, spleen and gonads. Two or more major peripheral nerves were additionally examined to differentiate between MD and AL as proposed by Goodchild (1969) and reviewed by Adene (1980). The period of ten years of study covered entries made from April 1975 to April 1984.

From the later part of 1983, an unusual trend in the prevalence of neoplastic cases was observed at the PDU. It was therefore decided to subject one of them (Case No. 83/12/166) to additional investigation and test the accuracy of our post mortem diagnostic methods. In one such cases involving a 15 week old batch of pullets which originated from Oyo State, specimens of the neoplastic tissues and feathers from live birds were subjected to histopathology and sero-diagnosis, respectively.

Histopathology: Samples of the liver, gonad and sciatic nerve were collected from Case 83/12/ 
186 for histopathological examination. The tissues were fixed in formol-saline for 3 days, trimmed, sectioned at about 6 microns and stained with haematoxylin and eosin before microscopic examination.

Radial immunodiffusion test: The test was performed as described by Haider et al. (1970) for the detection of MD viral antigen in feather tips Case 83/12/186. The template consisted of agar incorporating $5 \%$ hyper immune MD serum on a $7.5 \times 2.5 \mathrm{~cm}$ glass slide. Each slide carried three horizontal rows of feather tips each row of 6-8 feather tips representing a chicken. Nine chickens randomly selected from the flock were examined in this test. The agar plate was incubated at room temperature and read every 24 hours against an illuminated background. A control for this test was also set up using feather tips from isolation reared and unvaccinated chickens which were seronegative for MD, Newcastle disease and Gumboro disease.

\section{Results}

Pathology: The neoplastic lesions which were diffuse or focal, commonly affected one or more of the parenchymatous organs, like the liver, spleen and kidney which were therefore enlarged and greyish. The focal lesions produced nodules of varying sizes which in some cases, accompanied the diffuse types. Testicular involvement was characterized by diffuse enlargement and greyish discoloration of the organs. These changes were only readily noticeable when unilateral and the unaffected testis afforded good contrast. In the female birds, there was usually a functional regression of the ovarian follicles, many of which were displaced by or overgrown with, greyish and solid nodules of diffuse and cauliflower-like masses. Cases in which the affected organs (e.g. liver, spleen) were not only enlarged but also haemorrhagic, congested, or fatty were readily differentiated as non-neoplastic.

The tumours were classified on the basis of age of the flock, organ distribution and pattern of gross lesions. Thus all cases presenting detectable visceral neoplastic lesions and which included the testes or ovaries and any of the major peripheral nerves, were classified as MD. No attempt was made to differentiate between classical and acute MD. Other cases in which visceral neoplasms did not involve the gonads and peripheral nerves were classified as avian leukoses, particularly in laying flocks. The total of 22 cases of MD were diagnosed from flocks which were at pre-laying or early laying ages. There were 19 cases of AL, occurring in aged layers. No attempt

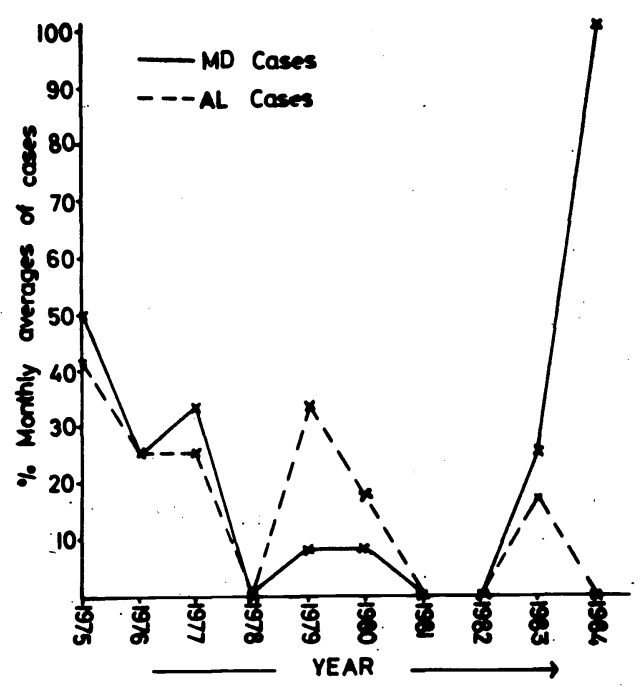

Fig. 1

Incidence of Marek's Disease (MD) and Avian Leukosis (AL) in the years 1975-1985 based on per cent monthly averages 


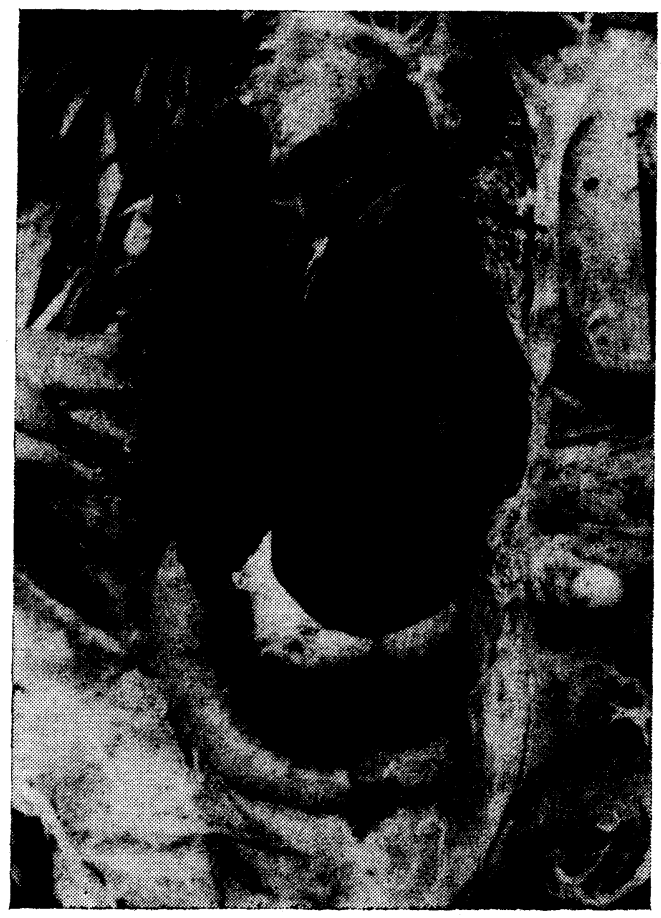

Fig. 2

Chicken liver affected with MD neoplastic lesions.

was made to differentiate between the 3 components of avian leukoses in this study. Seven (31.82\%) of all cases, between 1975 and 1984 were recorded during the last 12 months of the ten year period. The yearly trends of incidences are shown in Fig. 1.

Case No. 83/12/166: A batch of 300 pullets, 15 wk old, in Ibadan, Oyo State was involved. At post mortem examination, the neoplastic lesions involved the liver (Fig. 2) but also the spleen, kidneys and occasionally the gonad and peripheral nerves. Histopathology: the liver was infiltrated by a mixed population of lymphoid cells and plasma cells. The connective tissue in the ovary had been replaced by proliferative mononuclear cells. In the nerve, there were cellular infiltration, interneuritic oedema, perivascular cuffing of lymphocytes and moderate Schwann cell proliferation. MD was diagnosed on the basis of the above lesions.

A ring of precipitation lines appeared around some feather tips in four out of the nine rows $(44.4 \%)$ of feather tips from case $83 / 12 / 166$. None of the feather tips in the control group showed any ring up to 72 hours when readings were terminated.

\section{Discussion}

The differential diagnosis of Marek's disease and avian leukoses, the commonest visceral neoplasms of poultry is often difficult because of the close similarities between their gross lesions. Yet diagnostic records which fail to differentiate between them, as summed up by Adene (1975), can be very misleading, with serious implications for the epizootiology, surveillance and control of these two important groups of diseases of poultry. Thus for example, the upsurge in the trend of vaccine breaks and the so-called "hot strains" of MD virus (Witter 1982; Schat et al. 1982; 
Brown 1983), would have been unnoticed but for the existence of active surveillance which was based on accurate diagnosis.

In this study, we found the application of such data as age of affected flock, organ distribution of lesions, particularly the involvement of the gonads and of the nerves, to be very useful guidelines as proposed by Biggs (1961) and by Calnek and Witter (1972), for the post mortem diagnosis of MD. The histopathological findings on the test case No. 83/12/166 constituted a useful check on our diagnostic accuracy. Although the presence of MD virus antigen might be due to vaccine or field virus, the combination of age incidence and histopathological findings provided the conclusive diagnosis of MD for this case.

The recent wave of MD outbreaks reported here was preceded by a decline which was first noticeable after 1975 and most marked from 1977 to 1982 . Some of the outbreaks in late 1983 and early 1984 have been rather explosive in morbidity and mortality (unpublished field report). From the fact that the bulk of Nigerian commercial poultry is vaccinated from source and the traditional sources have not changed over the years, it could be speculated that the current wave in MD outbreaks in Nigeria might be due to Nigerian or imported "hot strains" of MD virus. It is hoped that this would receive a close study in the near future.

The call for the introduction of MD vaccination programme in Nigeria and other developing countries should now regain its lost steam not only because the reemergence of MD problem is a warning but also for the interest of the budding hatchery industry in these countries.

\section{Acknowledgement}

The authors wish to thank Dr. Owoade and Mrs. S. Sule for their assistance in the field and laboratory aspects of this investigation.

\section{Sledování prevalence Markovy nemoci a aviární leukózy v průběhu deseti let v Ibadanu, Nigérie}

V letech 1975 až 1984 byla prováděna diagnostika výskytu Markovy nemoci (MN) a aviární leukózy (AL). V tomto údobí bylo pitvou zachyceno a potvrzeno 22 prŕpadů $\mathrm{MN}$ a 19 prípadů $\mathrm{AL}$. Výskyt $\mathrm{MN}$ vrcholil v letech 1977 a 1983/84, zatímco výskyt aviární leukózy dosáhl maxima v letech 1977, 1979 a 1983. V letech 1977 až 1983 byl výskyt MN nízký a byl zřejmě důsledkem rozšiření aplikace vakcín proti této nemoci v krajinách $\mathrm{s}$ vyspělou produkcí drůbeže, $\mathrm{z}$ nichž pocházela většina v Nigérii chované drůbeže. $V$ práci je diskutován význam diagnostické surveillance Markovy nemoci.

\section{Исследование преобладания болезни Марека и авиарного лейкоза в течение десяти лет в Ибадане, Нигерия}

В 1975-1984 гг. проводилась диагностика наличия болезни Марека $(\mathrm{MN})$ и авиарното лейкоза (AL). В указанный период вскрытием было установлено и подтьерждено 22 случая болезни Марека и 19 случаев лейкоза. Наличие болезни Марека достигло своей вершины в 1977 г. и в 1983-1984 гг., между тем как наличие авиарного лейкоза достигло максимума в 1977, 1979 и 1983 гг. В 1977-1983 гг. наличие болезни Марека было низким, видимо, в результате расширения применения вакцины против данного заболевания в странах с развитым птицеводством; среди домашней птицы преобладали курицы, происходящие из Нигерии. 
В работе обсуждается значение диагностического контроля болезни Марека.

\section{References}

ADENE, D. F.: Studies on the types of neoplasms of poultry in Nigeria. J. Nig. Vet. Med. Ass., 4, 1975: 75-81.

ADENE, D. F.: Studies on the neoplastic diseases of local and exotic chickens in Nigeria with particular reference to Marek's disease. $\mathrm{Ph}$. D. Thesis, University of Ibadan, Nigeria, 1980, $298 \mathrm{p}$.

BIGGS, P. M.: A discussion on the classification of the avian leucosis complex and fowl paralysis. Br. Vet. J., 177, 1961: 326-334.

BROWN, R. H.: Suspected »hot « viruses lead to work on new Marek's disease vaccines. Feedstuffs, 55, 1983: 11 .

CALNEK, B. W. - WITTER, R. L.: Marek's disease - differential diagnosis. In Diseases of poultry - 6th Edition. Iowa State University Press, 1972: 496.

GOODCHILD, W. M.: Some observations on Marek's disease (Fowl paralysis). Vet. Rec., 84, 1969: 87-89.

HAIDER, S. A. - LAPEN-KENZY, S. E.: Use of feathers in a gel precipitation test for Marek's disease. Poult. Sci., 49, 1970: 1 654-1 657.

OKAZAKI, W. - PURCHASE, H. G. - BURMESTER, B. R.: Protection against Marek's disease by vaccination with a herpesvirus of turkeys. Av. Dis., 14, 1970: 413-429.

SCHAT, K. A. - CALNEK, B. W. - FABRICANT, J.: Characterisation of two highly pathogenic strains of Marek's disease virus. Avian Path., 11, 1982: 593-605.

WITTER, R. L.: The Marek's situation: breaks, variant strains, polyvalent vaccines. Poult. Dig., 41, 1982: 554-556. 